\title{
A Marxist interpretation of black attempts at political self-definition in South Africa
}

\author{
Pieter Coetzee \\ Department of Philosophy \\ University of South Africa \\ PRETORIA
}

\begin{abstract}
A Marxist interpretation of black attempts at political self-definition in South Africa

In this article I address the problem of political self-definition in South Africa. I altempt to trace and explain the rise of political consciousness among the black people of South Africa and indicate that the rise of political consciousness was expressed in a Marxist attempt at political selfdefinition This attempt has conceptual connections with communitarian politics, which explains why it was so easily accepted by black people. Black Consciousness made room for a wider political consciousness which included elements of traditional communitarian politics and elements of Marxism.
\end{abstract}

\section{Stating the problem}

How a community understands itself underpins its own cultural bias. In keeping with contemporary understanding of culture as an open-ended resource (Thornton, 1988:17), built up through history - a resource on which members of a community draw to mediate the exigencies of their everyday lives, a community's self-understanding is at any given time in its history the bedrock of its cultural capital, providing at once

- an interpretive framework for the generation of social meaning (especially as this relates to the generation of a political identity),

- a marker for the boundaries of social identity and choice,

- a conception of the social processes by which social and cultural goods are produced and distributed.

The integrated sum of these things we call a community's self-understanding. A community's self-understanding forms the bedrock of its social and political identity. A community's social identity is its characteristic way of life which members have sustained over a considerable period of time as an integrated 
cultural whole, and to which individual members stand in a dialogical relation i.e. one which supplies an interactive context in and through which they actualize their identities and exercise their choices.

A community's political identity is its characteristic forms of institutional organization - characteristic in the sense that these forms of organization reflect its cultural bias, and so provide distinctive avenues through which power is attained and exercised.

Ideally a community's political identity should grow out of its social identity. A community can be said to enjoy a coherent and stable social life if its political life simply is institutionalized culture. This view of a dependence relation between social and political identity poses some problems for culturally diverse and heterogeneous states like South Africa and, indeed, most of the African states. The problem here is that diverse cultural communities which do not inhabit the same world of shared social meanings and understandings co-exist within single political communities. Thus the following question arises: if political communities do not inhabit the same world of shared understandings, how do we conceive of the relation between social and political identity? The response to this problem by African thinkers and politicians in South Africa have been conditioned by their experiences under the existential and social conditions of the apartheid era. During the apartheid era this response took the form of a Marxist transplant onto a traditional communal (communitarian) form of social life. It is the object of this article to explore the history and philosophy of the marriage between tradition and Marxism.

\section{The background of white supremacy}

In South Africa the problem of working out an acceptable political structure for diverse cultural communities had been delayed by the apartheid system. For better or worse, the growth of a black culture of resistance - and with it a philosophy of liberation - was formatively linked to the search for an inclusive idea of political identity, one suited to culturally heterogeneous South Africa. But there were some major impediments to this search.

Vanous forms of hegemony of white over black - institutional as well as ideological - bequeathed a socio-economic landscape divided between a dominant white centre and a subordinate black periphery. This feature of white centre pitted against black periphery played a major role in legitimizing the fragmentation of South African society along racial and ethnic lines. The reduction of the black periphery to a marginalized area of social life became a legitimate process in virtue of the self-legitimizing authority of the dominant consensus of the centre. This is a typical feature of societies containing 
Pieter Coetzee

marginalized groups - in such societies the centre is usually the source of legitimation.

It is a truism to say that the social and political identities constructed in the centre were ones conforming to white conceptions. Witness how "whiteness" colonized the public sphere in which the common life of South African society is lived. White hegemony of the centre and white control of public space enabled the white middle-class to construct a picture of the universality and objectivity of its values, and through this claim to universality and to objectivity, to project a false view of the nature of a difference (McLaren, 1994:59-62). For a difference to be recognized as a significant difference (McLaren, 1994:55-59) requires that the claim to difference be offered in a specific social and/or historical context which is generally acknowledged or recognized as authoritative with respect to the alleged significance of the claim. For instance, the claim (often made in the journals of the Dutch Trekkers) that they, as whites, were the carriers of a superior civilization, has significance as marking a (perceived) difference between them and the indigenous peoples of Southern Africa. The significance of the claim as a marker of difference derives from a 19th century milieu in which it was offered as a justification for aggressive European expansion. Today we recognize the social and historical situatedness of the claim, and can deal with it as such. To recognize that the significance of the claim rests on its embeddedness in social and historical circumstances is to see it as one should - as a claim which has status as a marker of difference between white and black, but one which can be challenged simply because it has a place in a specific social and historical milieu. As a marker of difference it has no status outside this milieu.

In South African society the 19th century world-view of an expansionist Europe continued to prevail. Accordingly "difference" was seen to be a natural given, conforming to the order of nature (McLaren, 1994:59-61). In this context "difference" marked different essences (it is of the essence of being white to be superior, and of the essence of being black to be inferior), and essences were naturalized (the essential difference between black and white is a natural one, occurring as a matter of fact in nature) so it seemed that the social and racial stratification of South African society conformed to the natural order of things. As a marker of difference then, the idea of "white superiority" was removed from the social and historical setting in which such ideas standardly gain meaning, and so ceased to be (as it should be) a social and historical construction, becoming merely a tool of oppression.

\section{- The delegitimization of black languages}

This process of social and racial stratification based on the interpretation of "difference" as "naturalized essence" had a counterpart in linguistic stratification. No black language ever became an official language. The delegitimization of 
black languages as languages of the public domain had two major consequences: it denied black cultural groups a place in the articulation of our society's selfunderstanding and it undermined the role of their languages as purveyors of culture. It is not difficult to see why these consequences occurred. Language is one carrier of cultural symbols and meanings of groups and thus plays a crucial role in constructing social identities. To the extent that black languages were marginalized as languages of the public domain, to that extent their potential as rallying points of resistance to social and racial rank ordering were diminished. The result was that black cultural symbols, and the meanings associated with those symbols, failed to become part of the forms of social and political life which were articulated and constructed in the centre.

The point at issue here runs much deeper. A language maintains its role as the medium through which conceptions of social and political organization are articulated in a way which expresses a people's cultural bias, if its speakers are able to sustain their society as an integrated cultural whole over a long period of time. If not, a language loses its role as purveyor of culture. In South Africa the construal of "difference" as "naturalized essence" formed part of a racist discourse through which black languages lost this status. In a milieu of discrimination and oppression it is easy to lose sight of the proper status of "difference" as a social and historical construction and to accept a stratification of racial and linguistic differences as part of the natural order. It is not difficult to see that this stratification had the effect of elevating "whiteness" to a norm-setting position, above the social and historical situatedness which the authority of such positions standardly have. It is then no accident that the common life of South African society had been driven by standards of excellence and achievement which derive from the cultural capital of the white middle-class.

\section{- The asocial and ahistorical situatedness of the authority of normsetters}

The idea of an acultural, ahistorical position for the authority of normsetters, and the talk of "naturalized essences" which became part of their (hegemonic) forms of discourse, are good examples of how "truth" functions as a politicized commodity in repressive societies. It is largely through the role language plays in the construction of meaning and identity that the centre was able to manufacture a picture of its asocial and ahistorical situatedness, and to project an image of its standards as universal. For the white centre this privileged position had a significant spin-off. It became possible, by the same means, to construct pictures for others which they were persuaded to accept as constitutive of their self-image. Hence blacks absorbed the idea of their essential incompetence. Note how the alleged essentialist nature of differences between groups became the source and justification of a division of labour - for whites positions of responsibility, for blacks the lower ranks of the jobs market. Note also how the alleged universalism of the standards of the centre profited by identifying the achievements of 
European culture with the achievements of human civilization. The failure to see that these things are not co-extensive was part of the failure to criticize forms of discourse which give little or no recognition to the specific and distinctive values which other cultures have to offer (McLaren, 1994:49), and which undermine their roles as the context in and through which other people actualize their humanity.

\section{- Public space as locus of action}

All and all, black groups were reduced to the status of "add-ons" to the centre (McLaren, 1994:49). We have said that a difference can be a marker of rank. Qua "difference" then, "add-ons" signify a representation from the centre of groups accretively joined to a nucleus but which do not form an integral part of it. This notion of a "accretive addition" is best explained by considering the picture of public space it generates: a public space is any locus of "action-in-concert", the site at which common action is co-ordinated through argument and persuasion. In this space the topic(s) of conversation - of what gets included in the agenda - is usually something over which competing groups - including the "add-ons" - struggle. Participation in this struggle is a push for justice (a push for a public debate on some issue of unfairness)

Note, for instance, how various feminist movements had gone public over the question of women's rights, and forced a redrawing of the boundary between "private" sphere and "public" sphere, pushing the question over the status of women from the former to the latter in order that it may become debatable as a question within the realm of justice. Similarly, pressures from the periphery over the question of civil and political rights for black people has been an attempt to go public and let justice be done by challenging the centre's monopoly of power The kind of pressure which had been exerted clearly showed the limits of the white model of public space: it could maintain itself only by a highly questionable delimitation between social spheres, some of which were recognized as legitimate ones of public debate, others not. So, for instance, "labour" never figured as an item on the public agenda because this sphere of social life had become a centre of black resistance to white power. It became part of the public conversation only once the basis of its exclusion - the philosophy underlying the division of labour - had been challenged and overthrown. It is to this struggle in essence a struggle over the question of black political identity - that we now turn.

\section{The quest for political self-definition}

The black resistance movements understood their task in a certain way: They took themselves to be opposing a racist ideology, one which claimed that whites are - as a matter of fact, a given of nature - superior to blacks 
In very general terms ideology is usually described as a “'science' of ideas" which raises questions about the basis and validity of our most fundamental ideas - ideas like the proper ordering of social life, the nature of justice, the moral requirements of interpersonal relations, and so on. Ideological discourse is often contrasted with scientific discourse which, according to the preferred conception of the latter, is not value-laden (as ideological discourse is claimed to be), not dependent on any world-view or perspective (as ideological discourse is claimed to be), and aims at truth (which ideological discourse cannot do since it has no claims to objectivity or universality in all the senses of these terms). This latter point is particularly interesting since it encapsulates much of Marx's ideas on ideology (as formulated by Thompson, 1990:41). According to Marx

\begin{abstract}
... ideology is a system of representations which serves to sustain existing relations of class domination by orientating individuals towards the past rather than the future, or towards images and ideals which conceal class relations and detract from the collective pursuit of social change.
\end{abstract}

In other words, ideology masks truth by propagating untruths. As Thompson (1990:35) makes the point that "ideology ... is a theoretical doctrine and activity which erroneously regards ideas as autonomous and efficacious and which fails to grasp the real conditions and characteristics of social-historical life".

There are at least two critical themes which we must take note of implicit in Thompson's formulation of Marx's approach to ideology. We have already touched on them. They are:

- The erroneous asocial, ahistorical treatment of the notion of a difference through which whites aspired to dominate blacks, and the false asocial, ahistorical position of the authority of the white normsetters through which the values of Western culture aspired to universal status

- The inequitable and unfair division of labour which has thrived on the false propositions mentioned in the previous sentence.

Thompson's formulation of Marx's approach to ideology is a pointer to the falsity of racism, especially in its institutionalized forms. According to Marx all systems of thought and ideas are always embedded in and determined by social and historical conditions, especially in the material conditions of social life (McLellan, 1986:17). On his assumption of the social determination of human consciousness there can be no system of thought or ideas which have claim to truth outside a social and historical context. This pushes white claims to a natural superiority back into a social and historical context where it can be exposed as the orthodoxy of a group intent on maintaining its power. The division of labour between "mental" and "manual" thrived on a false sociology, one unconditioned by the material conditions of social life and a history of production. This false 
sociology produced a class division between black and white, the former becoming a labour class, the latter an entrepreneurial class with control over the means of production.

Marxism offers a particular view of the nature of society. According to Marx society is constructed by the way in which human beings respond to their material needs (needs for food, shelter, work, leisure time, and so on). Since these needs are satisfied through their labour (Kessler, 1987:41), Marx recognized labour as the fundamental human activity, and held that the only valid social science will be one which accepted labour as the starting point of theorizing about society. So all social practices had to be explained with reference to labour, and this included the division of labour which prevailed in any society since the division of labour determined all social and economic arrangements. Marx believed that this starting point in labour secured for Marxism the only possible "correct view" of society, and as such it generated a useful critique of society: in any society in which an uneven distribution of power and resources prevailed, an ideology could be found, masking perceptions of a "true account" of its proper social and economic organization (McLellan, 1986:14-16). Thus, in South Africa, a racist ideology created the illusion that the division of labour between "mental" and "manual", and the concomitant unequal distribution of power and resources were glimpses of a true reality in which whites were the "natural" leaders. What makes these racist ideas ideology (and hence false) was their distortion of the fact that at bottom the conflict in South Africa was a class conflict.

We have said that a racist ideology falsely portrayed South African society as cohesive rather than conflictual (as it in fact is), and falsely attempted to justify an unequal distribution of power and resources with reference to a "natural order of things". If we look beyond ideology we will see that South African society is indeed conflictual in nature, and that this conflict is due to two factors:

- The division of labour, between "mental" and "manual" which empowered only whites, placing them in positions of economic and political power.

- The creation of an open market economy, and a community in which individuals compete for motives of self-interest, with the concomitant loss of traditional communal social organizations in which the interest of the individual coincided with that of the community.

The first above-mentioned idea is an unwanted consequence of the second. The exploitation inherent in the relations between the white capitalist class and the black labour class was conceded by the illusion of a free society based on the free exchange of commodities. The kind of community which developed was the very antithesis of what (in Marx's view) community is all about. We return later to 
A Marxist interpretation of black attempts at political self-definition in South Africa

this point. Here we merely note, in summary form, the negative picture Marx presents of a class-divided society like South Africa.

In South Africa the best-off class (the whites) was also the ruling class i.e. its interests were served by the major political institutions, which included using all instruments of coercion in favour of the best-off class, at the expense of the labouring class (the blacks).

It follows that the social arrangements acceptable to the best-off class would never be acceptable to the labouring class, and hence that a state of conflict prevailed.

It also follows that inegalitarian distributions were likely to remain in force for as long as the best-off class strived to maintain its privileged position - unless, of course, it could be overthrown by force or any other means

What makes ideas ideological was that they masked the true nature of society, creating the illusion that an unequal distribution of social and economic resources was symptomatic of the proper ordering of relations between the classes. In other words, free exchange in a capitalist economy was simply a cover for a distribution in which one class (the whites) exploited another class (the blacks). Marx was intent on showing that a certain kind of social determination of thought led to ideological thinking.

Marx, however, operated on the assumption that all thought is socially determined: There can be no system of thought and ideas which have a claim to truth outside the social/historical context in which thought and ideas arise. So, if this was true, Marx's so-called "correct view" of society - the whole picture of understanding social arrangements in terms of labour, production and distribution - must be ideological too (McLellan, 1986:19-20). Marx did not draw a clear distinction between the idea of socially determined thought and ideology in so far as he did not clearly show what kind of social determination produces ideology. Marx can clearly not accept the view that all socially determined thought must be ideological, for this view turns his "correct view" of society into ideological thoughts as well. Yet Marx continued to call all systems of thought which perpetuate relations of domination (of ruling class over labouring class) ideological - a system of thought which he contrasted with his "correct view", and which he thought was the only correct (socialist) view.

\subsection{A Marxist attempt at political self-definition}

Black resistance to white oppression developed into a quest for political selfdefinition. The initial attempt at political self-definition was modelled on a Marxist conception of the just political order. Consider the following view: 
Pieter Coetzee

Examining Black Consciousness as an ideology capable of challenging the cultural hegemony of the white supremacist regime entails understanding the movement as the ethico-political weapon of an oppressed class struggling to reaffirm its humanity. ... It would be wrong to equate the Black Consciousness movement with a mere cultural renaissance; it was indeed more than that. Black Consciousness recognized the centrality of the material conditions of existence and it was precisely because of these that it rejected collaboration with whites ... (Falton, 1986:57-58).

The agenda for the creation of a Marxist political state began with the identification of the black existential condition as that of

- a labouring class, and hence

- a socially exploited group, intent on

- ending its exploitation by rising to political self-definition and power.

The Black Conscious Movement (henceforward the Movement) recognized that since colour determined the privileged position of whites, there could be no alliance between black and white workers. White workers could not be regarded as genuine workers - as members of an oppressed and exploited class - as long as they enjoyed white privileges (job reservation, higher wages, recognition of trade unions etc.) (Falton, 1986:84). Consequently, a genuine working class which is formed when persons who perform the same function in the production process unite to defend their common interests - did not develop for whites to the extent that it developed for blacks. Indeed, the Movement determined that all participants in white privilege were accomplices in oppression on the grounds that to participate was to fail to prevent crimes being committed against humanity. This meant that whites who were opposed to the apartheid system could not be included in the Movement since they were participants in the system.

These "liberal" whites had to be watched lest they arrest and blunt the edge of black revolutionary zeal, for their "'mosaic' multi-racialism"1 was simply a cover for the maintenance of white power and privilege. The goal of racial integration propounded by these whites was a futile political gesture as long as white norms in culture, economics and morality remained ascendant. The critical point is that white norms represent the individualism of the privileged class which was opposed to the communal outlook characteristic of African society. Falton (1986:86) expresses the point as follows: "It [the Movement] condemned the conditions of everyday life, the capitalistic-induced erosion of communual solidarity, and African corporate personality."

I This expression is adopted from Ranevedzi Nengwckhulu - quoted in Falton (1986:84). 
The Movement had to exploit the solidarity of African culture, and African cultural groups had to coalesce into a solid power block to bring down the white power structure. This meant, in effect, reviving the "consensual foundations" (Falton's expression - 1986:86) of African culture.

\subsubsection{Towards self-definition: The social thesis}

All persons have (legitimate) interests which they seek to promote through the channels which institutional structures create. The social preconditions for the effective fulfilment of a person's interests are linked to a cultural context which gives form to these conditions. One crucial condition is the creation of a context of choice in and through which people actualize themselves. The social thesis which shall briefly be discussed is an essential ingredient of traditional communal (communitarian) social organization onto which a Marxist picture of selfunderstanding was grafted (Hountondji, 1983:142-147). In this respect some features of the traditional picture which played a role in the development of a hybrid Marxism will be indicated.

The particularity of one kind of a communitarian model is perhaps best exemplified by examining some of the essential social conditions which unite a community's social and moral identity ${ }^{2}$ (Wiredu, 1992:80-93). It is a major assumption of the approach adopted in this article that the capacity for moral choice and development can only be exercised in a cultural setting which makes provision for its growth. Let us call this the social thesis. The social thesis describes the self-understanding of one kind of community and, as formulated below, shows one version of the social meaning of communitarian perspectival models. According to the social thesis an individual's choice of way of life is a choice constrained by the community's pursuit of shared ends. This pursuit of the common good is the primary goal of the political community and always takes precedence over the pursuit of individually chosen ends. Communual ends cannot - all other things being equal - be overridden or vetoed because shared ends have much greater weight (value) in the life of the community than other ends. The common good is conceived of as being good because it fits the patterns of preferences of individual members; this common good is not single-faceted, but implies many aspects, each fitting a sphere of social life and resting on a consensus (agreement) about its value. The common good, then, define substantive conceptions about the good life - identified for application in specific social contexts. The good life for an individual is conceived of as coinciding with the good of the community, and a person's choice is highly or lowly ranked

For my insights into African communitarianism I am indcbted to Wircdu (1992). 
according to the way in which it contributes to or detracts from the common good.

The social thesis describes linguistic communities (Bell, 1995:157-165). A linguistic community has a history and various traditions (of morality and reasoning) which inform the narratives of individuals' lives and link them to those of their ancestors. Languages embody distinctive ways of experiencing the world and thus play a crucial role in defining the experiences of a community as their particular experiences. Since language is a determinant of a particular outlook it is one significant factor that shape a way of life. Speakers communicate with each other about their common history and have access to the significance of events in it in a way not communicable to non-speakers, or in other languages. This means that language never is just a neutral medium for communication or for identifying the contents of actions - rather language itself is content, a valueladen reference for communual loyalties and animosities.

The social thesis also describes a community of mutuality (Wiredu, 1992:80-93), one in which each member stands in a dialogical relation to other members, i.e. a relation which requires the recognition of reciprocal obligations. In a community of mutuality members recognize that since the (personal) projects they pursue, and through which they give meaning to their lives, projects are made available by a cultural structure. Thus they have - all other things being equal - a duty to sustain these structures. In so far as the recognition of the need to preserve a cultural context is the prerequisite of a meaningful life, it derives from the social meaning of a socially embedded notion of obligation.

According to the social thesis the community (and not individual members) is the locus of deontology ${ }^{3}$ (Wiredu, 1992:80-93). The argument about morality and reason takes place within traditions. A major assumption of this attempt to contextualize the argument is that beliefs about morality and reason cannot be successfully justified in detachment from actual ways of life and the social meanings embodied in them. This point encapsulates the status of the community as the locus of deontology. The community is the focus of moral identification and hence those collective decisions always have overriding moral authority. The collective decision cannot be trumped by individual decisions because identification with the common good as the focus of allegiance must remain paramount. The tension generated by the ensuing struggle between tradition and modernity is a familiar one: the longer a particular interpretation of a social practice goes back in time, the greater its historical significance. Traditions embody many years of communual effort and thought, and it is unlikely that a

3 For this insight I am indebted to Wiredu (1992) 
A Marxist interpretation of black attempts at political self-definition in South Africa

deeply held view will have failed to get something right regarding truth. But though deeply held views have historical depth in the sense just outlined, they are open to reinterpretation. Open-endedness is a general feature of African traditions, so there is in principle no difficulty with reinterpreting the notion of "deeply held" to mean what is currently of greater importance or significance for a community (even if this conflicts with the commitments of a community's ancestors.)

\subsubsection{Towards self-definition: The Marxist thesis}

The social thesis we have examined forms part and parcel of the idea of a communitarian ethic and community oriented policy. It forms part of the traditional African picture of values (Hountondji, 1983:142-147). This picture, however, has been significantly modified by input from Marxist ideology as a consequence of the racial stratification of society in South Africa. In this section we shall take a critical look at the Marxist overlay in an attempt to see clearly what the lure of Marxism added to black attempts at political self-definition.

The infiltration of Marxist ideology into traditional black conceptions of social and economic life had a significant consequence: black intellectuals identified an open market economy as the backbone of the apartheid system. Falton (1986:45) makes the point as follows:

It is precisely because racism was such an active ideological force encroaching on the material base of society, that the South African political economy developed as a Volkskapitalisme. ... Volkskapitalisme is a social system in which a racially determined hegemonic core, controlling the state, drains the economic surplus from a racially determined subordinate periphery.

If Falton is right, racism was the main mover in the consciousness of black intellectuals towards the identification of white political and economic arrangements with an oppressive capitalist system. For them Marx's labour theory provided a theory of politics. Now, being a phenomenon articulated in specific contexts, politics is the ways and means by which social conflict and notably class conflict is manifested and managed. Marx clearly gives great weight to economic arrangements in his critique of society. "The mode of production of material life conditions the social, political and intellectual life process in general. It is not the consciousness of men that determines their being, but, on the contrary, their social being that detarmines their consciousness" (quoted in Miliband, 1990:7).

But this weight is due to Marx's belief that human emancipation can never be achieved in the political realm alone, but requires revolutionary transformation of the economic and social order of capitalist society. Of course, in the Marxist 
scheme of things, politics was taken to be an expression of alienation, and emancipation was taken to mean the end of this alienation - in effect, the end of politics. Politics, then, was seen to have a determinate function: it is a necessary stage in the development towards the post-capitalist state, and as such it is an activity whose end is its own annulment.

\subsubsection{Labour, conflict and alienation}

The idea of conflict lies at the core of Marxist politics. In the Marxist scheme of things conflict is caused by a state of domination (by the capitalist classes) and subjection (of the labouring classes), which is to be ended by a transformation of the conditions giving rise to it. For Marx conflict is inherent in the class system: domination and subjection are features of class societies, and are based on specific features of their modes of production (McLellan, 1986:17-18). The essential feature is the distribution of the material and moral goods of a society a process, put and kept in motion by the dominant classes, to appropriate the greater share of a society's wealth, in order to maintain, strengthen and extend their dominant position.

Conflict is generated by the exploitation of labour and the distribution of the products of labour. Marx identified two areas in which those who controlled a society's modes of production maintained relations of domination and subjection:

- Regarding "relations of production" (quoted and discussed in Kymlicka 1989:100-131) Marx believed that the mode of production dehumanized the worker in her position in some production process, reducing her a cog in a machine with no control over the system which needed her labour.

- Regarding "relations of exchange" (quoted and discussed in Kymlicka 1989:100-131) (i.e. distribution), Marx believed that the open market served only the interests of the governing classes, i.e. it was the arena in which the labour of the worker advanced the material and moral needs of others.

In societies in which the modes of production served the ends of domination, the worker was denied her true nature as social being in three ways: 4

- Relations of production separate workers from the individuating functions of their social roles, making it easy for them to be exploited as a labouring class. Relations of production become exploitive not only in the sense that workers are unable to discover the good in their roles, but also in the sense that they become the means to the enrichment of someone else in the ruling class. 
- Relations of production alienate (separate) the worker from the products of her labour, from herself in so far as the individuating function of a social role is denied her, and from society, in so far as she has no voice in the articulation of her community's self-understanding.

- Relations of production divide the workers' life into a "private" and a "public" sphere, the latter becoming the domain of the ruling classes, and public institutions' instruments of class rule. The point to note here is very significant: the public sphere of social life is supposed to be the arena where all individuals pursue the common good as their individual good. It is in this arena where social forces meet and engage in dialogue in order to determine the community's political agenda. Social forces, then, are always (potentially) political forces. Social forces gain political clout when they gain a foothold in the public forum, because then the issues they wish to discuss become issues about justice. All this means that, if Marx is right, the ruling classes have silenced the political will of the labouring classes by their control over the public sphere.

\subsubsection{Class consciousness and the classless utopia}

By regarding the worker as a class against capital, Marx assigned a political criterion to the notion of a working class (Miliband, 1990:22). For Marx no class is truly a class unless it acquires the capacity to organize itself politically. Being politically organized brings with it the notion of a "class consciousness" (Miliband, 1990:31-41) - the consciousness which the members of a class have of its "true" interests. What are the workers' "true" interests?

If Marx is right our "true" interests are satisfied through labour; labour is the fundamental human activity, and the only valid starting point of theorizing about society. All social practices have to be explained with reference to labour, including the division of labour between "mental" and "manual". Marx believed that his starting point in labour would secure for Marxism the only possible "correct view" of society, and as such it would generate a useful critique: in any society in which an uneven distribution of power and resources occurs, and ideology could be found masking perceptions of a "true account".

What makes ideas ideological for Marx, then, was that they masked the true nature of society, creating the illusion that an unequal distribution of social and economic resources was symptomatic of the proper ordering of the relation between the classes. The "true account" - an account focusing on labour and class-conflict as constituting the proper ordering of relations - must show that free exchange in a capitalist economy was simply a cover for a way of distribution in which the ruling classes exploit the labouring classes. In other 
words, the "Irue account" must strip the ruling class of its ideology, and expose it for what it is.

Thus it was necessary to show that the ruling classes engage in deliberate deception, whereby their spokesmen (or "ideologues") attempt to persuade the subordinate classes of the universal validity of principles (of social and economic organization) which they know to be partial and class-bound, but which they propagate for its utility in the maintenance of the given social order. But this is just one side of a fake coin. The other side portrays the working classes as a constituent of a universal social order in which their labour has a subordinate place. But labour, for Marx, is the primary constituent of human culture. This being so, a radical rupture with tradition - especially traditional property relations - is called for (Miliband, 1990:36). Only the labouring classes are capable of acting on behalf of society, to remove from it the greatest impediment to the realization of true human nature, viz, the capitalist mode of production. In sweeping away the traditional modes of production, the working classes will also have swept away the conditions for the existence of class conflict, as well as the very notion of a class itself. This end-point of the class-less society Marx identified with the arrival of the communist utopia.

Marx's idea of the "class-consciousness" of the labouring classes, then, may be taken to mean the understanding that the emancipation of the working classes, and of society, require the overthrow of the capitalist system, and the will to overthrow it. With respect to the latter, Marx talked of a revolutionary consciousness which involved a very definite political agenda. What was this agenda, and how was it argued for? As indicated above, the capitalist system failed to treat people as equals in two areas of social life, in "relations of production" and "relations of exchange". In these contexts the ruling classes did not see themselves as responding to the legitimate labour-related needs of others; indeed, in society they created social interactions which subverted the recognition of these needs.

What would constitute a recognition of these needs? Marx thought that the political agenda of the labouring classes must give prominence to an equality principle (discussed in Kymlicka, 1989:100-131), which was expressed as follows:

\section{- Labourers have an equal right to the products of their labour}

This principle has, however, to be qualified. We may make this point in terms of the familiar distinction between an equality of regard and an equality of outcome. With regard to the former, Marx maintained that all labourers are equally creators of culture through their labour, and that this entitled them to an equality of consideration (respect, dignity). In practice this meant that all labourers are entitled to equal consideration regarding the satisfaction of their needs and 
desires. It did not mean that everyone's needs and desires should be equally fulfilled, as an equality of outcome requires. Marx favoured the idea of an equality of regard since it makes provision for unequal talents and unequal needs, which demand an unequal distribution of the products of labour. So the equality principle had to be amplified by the addition of the following:

- To have an equal right to the products of one's labour is to have an equal right to unequal labour

The modified principle meant that if you have greater talents, then a greater labour output is required of you, and if you have greater needs then you are entitled to a greater share of the total labour output, irrespective of whether you produced the products of labour or someone else. For Marx unequal talents and unequal needs are relevant moral differences between persons, which must be acknowledged in the distributive patterns of social institutions. So, in Marx's good society, the following principle of distribution is the right one:

- From each according to his talents, to each according to his needs

Some observation of the latter point is called for. First it assumes a particular view of the nature of free choice. Briefly, the whole point of sustaining a society run on a labour agenda is to abolish classes and class conflict. This agenda protects the avenues through which the labouring classes arrive at political selfunderstanding, and as such creates a context of choice for them. But acceptance of the proposed political forms will lead to limitations on choice of forms of the good life. This is unavoidable, though the reason should be obvious: the moral and material goods available to workers are all goods internal to a cultural structure (Buchanan, 1982:32), which is to say that these goods are available to them through their performance of structured roles in the labour market.

But we should take care not to misread the limitations in this view of what constitutes choice. Marx offers a picture of the emergence of the social individual as the foundation of the good society. The social individual is intended to replace the competitive individual which capitalism creates in two areas of social interaction: "relations of production" and "relations of exchange". In these two areas of social interaction conflicts arise from the very nature of the unchosen relations between individuals. Now, as I understand Marx, the creation of the social individual will eliminate conflict since the social individual labours for the community (i.e. asserts no unjustified rights-claims to the common wealth). Note Marx's claim in this regard: "relations of production" and "relations of exchange" are social processes in which affective ties between individuals will eliminate unchosen conflicts (Buchanan, 1982:31-35). In the communist state a social identity (as "labourers of the common good") is a precondition of informed choice. Social interaction in the labour field would be governed by such choice, and would accordingly be harmonious (and not conflictual), because no one would choose ends which are in conflict with the common interest 
Has Marx got hold of the truth here? One defence of Marx's notion of choice runs as follows (discussed in Kymlicka, 1989:100-131):

- If we try to stand outside the roles of society to arrive at a perspective from which to judge the value of a choice (of way of life), we run into emptiness. The instruction freely to choose a way of life gives no direction for choice, for such "freedom" offers no determinable criterion of what way of life is good. We will not know that our choices are worth pursuing. This is because our ideas of what it means to lead a valuable life is a consequence of our doing things directed at specific ends within a social context which provides criteria of worth and value. Free choice understood as something which has inherent worth or value is something we arrive at as a consequence of action directed at or dedicated to other socially determined ends. In a Marxist society, geared as it is towards self-realization, no one is concerned with self-realization as an end which can be isolated and pursued for itself; they are rather (if Marx is to be believed) concerned with their work - achieving or realizing the goods internal to their roles in labour - as the means to freedom and self-realization. Freedom and self-realization come about as a consequence of the achievement or realization of their roles and purposes in the social fabric - specifically in the context of labour

Another line of defence runs as follows: Marx's social individual cannot be a person whose freely chosen projects deny her social nature. This is because, in a communist state, choice is informed by social identity. In the communist state the worker sees her labour as satisfying her most important needs, and hence as her most important project. This makes for a co-operative way of life. If Marx is right, co-operation would outstrip competition because no one has any advantage over anyone else with regard to control over the instruments of social and political power. Indeed, control would strictly be unnecessary because in the communist state the administration of justice would not only be superfluous (there would be no need for competition over limited resources), but also undesirable (competition for resources - limited or otherwise - would be dysfunctional).

- Secondly, the labour theory of politics emphasizes "relations of production" and "relations of exchange" as the foundation of social interaction, and not notions of distributive justice (discussed in Buchanan, 1982:50-69) According to Marx, as long as problems of distributive justice sit at the centre of our thinking, communities will be divided, and sectarian interests prevail In such divided communities appeals to (redistributive) justice are attempts to remedy defects in the community. Such appeals are needed because the community is defective, being merely an arena in which persons act from motives of self-interest in competition with others, rather than the arena in 
which members accept responsibility for fellow members in co-operative pursuit of the common interest. The good communist community will have no need for appeals to (redistributive) justice and indeed, no need for justice, because members will make no (conflicting) claims to resources they regard as solely theirs. The point is, if the community as a whole had an identity of interests, and members are bound by affective ties, justice is superfluous because no one needs to regard herself as a bearer of rights who can at any time become involved in interpersonal conflicts over claims to resources conflicts in which it is necessary to assert rights. ${ }^{5}$

A communist community will be one in which the communal interest remains paramount, and this requires the abolition of the division of labour between "mental" and "manual" which has characterized capitalist systems of production. The abolition of this division of labour will mean the abolition of private property, and with it one important cause of conflictual relations between persons. The real evil that attaches to conflictual relations is that they are unchosen: workers find themselves in competitive relations with other workers, which require that they regard others as the means to the satisfaction of their interests and this breaks down a sense of community in that an individual's development and growth can be bought only at the expense of others. Such conflictual relations must be replaced by a sense of sociality based on productive work for the sake of the community. This sense of sociality would replace the need for justice because individuals would cease to have (unchosen) conflicting ends.

- Thirdly, the labour theory of politics seeks to create a revolutionary platform (Miliband, 1990:43-52). According to Marx,

[t]he ideas of the ruling class are in every epoch the ruling ideas: i.e., the class, which is the ruling material force of society, is at the same time its ruling intellectual force. The class which has the means of material production at its disposal, has control at the same time over the means of mental production, so that thereby, generally speaking, the ideas of those who lack the means of mental production are subject to it (quoted in Miliband, 1990:49).

Marx's main target is, of course, the labour process itself, in particular, the division of labour between "mental" and "manual". Capitalist "relations of production" are, Marx argued, hierarchical, authoritarian, instilling in the worker a sense of subordination as part of the working-class culture. The cultural fall-out of top-down authoritarian structures are, in the capitalist framework, strongly

For the communitarian interpretation of Marx I am indebted to Buchanan (1982) 
pervaded by commercialism and money values. The institutions through which the ideological hegemony of the ruling classes was maintained, was controverted by Althusser (a follower of Marx) as "ideological state apparatuses" (Miliband, 1990:54) (e.g. the system of different public and private schools, the system of different political parties, state controlled media), the object being to show that the dominant capitalist class, under protection of the state, employs vast state resources to bring its own weight to bear on civil society. This blurs an important distinction between state and class power. Class power is power which a dominant class exercises to maintain its predominance in civil society, and as such may be legitimately challenged by any other (class-based) counter power. State power is something different. State power is neutral power (not the prerogative of any class or pressure group), and is exercised through state institutions (e.g. police), and only in areas where a general consensus of opinion in the community permits its use. Things go wrong as soon as class power is exercised through the agency of the state, because the privileged class then commands vast state resources to oppress its opponents. When this happens the state itself enters into the "consciousness" creating industry (Miliband, 1990:49. 55 ), thereby obliterating ideological apparatuses which have an emancipatory function in civil society, turning them into state apparatuses where they lose this function.

The last points made here are important pointers to the Marxist theory of political culture. The Marxist analysis of conflict in the state as class-conflict, centred in the concept of labour, implies that Marx did not see the capitalist state as the trustee of society as a whole (Miliband, 1990:66-74). Rather, the working classes are society's trustees. The idea that the capitalist state can be society's trustee is, in the Marxist scheme, simply an ideological veil which the ruling, capitalist class draws over the reality of its class-rule, so as to legitimate that rule. So the institutions of state - the law courts, the police force, the defence force, systems of education etc. - are never neutral, nor can they ever be neutral arbiters of competing class interests. The state and its institutions are partisan. The ruling class not only owns and controls the predominant part of the means of material production, it also owns and controls the means of "mental" or "psychological" production. This is not a propagandistic point: the claim, rather, is that once class power is translated into state power, the state loses its central function of neutral administration. Marx's labour theory of culture proposes that any unification of class and state power can only serve the interests of the ruling class, because the state becomes an instrument of the ruling class, i.e. it acts at the behest of the ruling class. The state, in fact, becomes a class state: it acts for the purpose of maintaining the existing system of domination through a system of centralization and the creation of monopolies. The creation of a class state is, in Marx's opinion, the outcome of an ideological-cultural persuasion which his own theory was meant to counter. 


\subsection{Communitarianism and Marxism}

I have attempted to show what lure Marxism had for black intellectuals. In the political consciousness of black intellectuals the remedy was seen to be the creation of a certain kind of community, one in which the goods internal to communal relations (especially economic relations) are also personal goods. The working classes could be freed, and equality restored, by freeing people from alienation, which meant restoring the identity-defining function of their social roles and gaining a voice for them in the articulation of the community's selfunderstanding - in effect organizing the labour classes into a political force.

The lure of Marx's picture of the good society can be explained with reference to the idea that in Marx the communal interest remains paramount, and this requires the abolition of the division of labour (between "mental" and "manual") which has characterized capitalist systems of production. I wish to argue that the labouring process, as explanatory model of social evolution, combines a traditional communitarian picture with an overlay of Marxism precisely because a racist ideology created racially divided classes. The racial character of relations between labour and capital were, in effect, the organizing principle of South African communities. Political power, the power of the state, played a primary role in the process of integration, providing the necessary social preconditions for the existence of a capitalist economy. The political system was thus justified with reference to its consistency with policing the requirements affecting relations of production and exchange between labour and capital.

The link between communitarianism and Marxism is a consequence of historical factors rather than a conceptual link. Paulin Hountondji (1983:146), commenting on the philosophy in Nkrumah's Consciencism, observes that the book was a response to a classic objection:

\footnotetext{
... that in adopting socialism, Africa would be delivering herself to an imported ideology and betraying her original civilization. It was precisely this issue, inspired by the most traditionalist cultural nationalism, that Nkrumah tried to address in Consciencism. The object of the book was to link socialism with the purest African tradition by showing that socialism, far from being a betrayal of this tradition would actually be its best possible translation into modern idiom.
}

In the 1964 edition of Consciencism Nkrumah states the link as follows (quoted in Hountondji, 1983:144): "But because of the continuity of communalism with socialism in communalistic societies, socialism is not a revolutionary creed, but a restatement in contemporary idiom of the principles underlying communalism."

However, in the 1970 edition Nekrumah is no longer so strident. 
But because the spirit of communalism still exists to some extent in societies with a communalist past, socialism and communism are not, in a strict sense of the word, 'revolutionary' creeds. They may be described as restatements in contemporary idiom of the principles underlying communalism (quoted in Hountondji, 1983:144).

According to Hountondji, the 1970 edition accepts two premises denied in the 1964 edition. They are Nkrumah's acceptance of the erroneous 1964 view that, prior to colonialism, class-divisions were unknown in Africa, and the acceptance of "the universality of class struggle" (Hountondji, 1983:146) as the basis of all political revolution. Indeed, Nkrumah closely identifies colonialism with capitalism - "a colonialist structure is essentially ancillary to capitalism" (Hountondji, 1983:144) - just as black intellectuals in South Africa identified racism with capitalism.

Hountondji identifies two problems in the way of realistic attempts at defending political identities in Africa. First, the attempt to oppose traditional African cultures to the colonizers" cultures tends to "flatten" the traditional cultures, i.e. it denies them their "internal pluralism", which, secondly, gives rise to a "backward-looking" cultural nationalism, and which, most importantly, says Hountondji (1983:162) " divert the attention of the exploited classes from the real political and economical conflicts which divide them from the ruling classes under the fallacious pretext of their common participation in 'the' national culture".

Hountondji clearly has great sympathy with Nkrumah's 1970 insights. He clearly sees Marxism as the African alternative to capitalist colonialism:

We must promote positively a Marxist theoretical tradition in our countries - a contradictory scientific debate around the work of Marx and his followers. For let us nor forget this: Marxism itself is a tradition, a plural debate based on the theoretical foundation laid by Marx (Hountondji, 1983:183 - emphasis added).

Hountondji's remark concerning participation in "the" national culture is meant to bring home the idea that colonialism has "arrested" African cultures by "reducing their internal pluralism" (Hountondji, 1983:166), a view he shares with Nkrumah: "Capitalism at home is domestic colonialism" (from the 1970 edition of Consciencism, quoted in Hountondji, 1983:144).

So there is in essence a conceptual discontinuity between Africa's "internal pluralism" and its Marxism. Is this true? Hountondji's unstated premise is clear: the idea of the national culture is a colonial import, aided and abetted by capitalist economic structures - an idea which is in conflict with domestic pluralism 
(conceived as community-centred social organizations). But just how does Marxism fit the domestic picture?

I have argued that the connection between traditional forms of social organizations (communitarianism) and Marxism is historical rather than conceptual - and my argument has been that in South African society racial stratification has been the most significant historical factor accounting for the appeal of Marxism. It is true that communitarians and Marxists adopted much the same view of justice. Justice is in essence a remedial virtue, a remedy for some defect in community. But regarding the nature of the defect there is much dispute. Communitarians standardly appeal to the remedial virtue of justice as a way of settling (potential) conflicts between different conceptions of the good. Since any account of justice is a cultural account, based on a supposed identity of interests among members of a (political) community, conflict is viewed as dysfunctional, i.e. as destructive of the common good. Marxists, on the other hand, view the defect in the community similarly as a conflict of interests, but accounts for it in terms of the division of labour which sets worker against worker in unchosen conflict (competition) by which each can develop only at the expense of the other.

But, these differences of emphasis in what each takes to be the defect in community notwithstanding, it seems to me that Marxism found favour because, given the circumstances in oppressive colonialism (including its racist forms in South Africa), it served as a tool of social critique.

Marx's concept of the labouring process provided a critique of South African society. Now, I believe that Habermas (quoted in Sensat, 1979:41-54) is wrong in arguing that Marxist theory cannot serve as critical theory because it overlooks the important point that production and socialization are two distinct dimensions of social evolution. Production refers to the appropriation of natural resources by society for the satisfaction of human needs (a process Habermas calls "purposiverational action" (quoted in Sensat, 1979:42). Socialization is the process by which people adapt to society through communicative action. This is the process leading to a division of society into two domains - the "public" (which deals with issues of justice) and the "private" (which deals with issues about the good life, and in which individuals are autonomous). Production is governed by technical rules, and socialization (communicative action) by social norms validated by consensus achieved through normed discourse. Both socialization and production are subject to the validity claims of social discourse.

Rationalization according to Habermas means theoretical-technical insight into the realm of "production", and practical insight into the realm of "socialization". Indeed, two distinct social domains are at issue here: corresponding to the "public" and "private", the former is manifested in the development of productive 
(technological) forces, the latter in extending communication free of domination. The role of critical theory is primarily (though not exclusively) to focus on the sphere of socialization and specifically, to develop critiques of ideology in the interests of emancipation, since such critiques help to dissolve the barriers to the discursive solution to moral and political problems. According to Habermas, Marx did not see that developments in these respective realms are logically independent of each other, and so failed to recognize socialization as a dimension of social evolution distinct from production. Marx attempted to reduce the communicative dimension to labour, i.e. to production, and this was because “... Marx unwittingly rules out reflection as a motive force in history by categorizing the self-generative process of the human species as a labor process" (Habermas quoted in Sensat, 1997:69).

The upshot is that Marx's interpretation of history (as the self-generation of the human species through labour) led him to believe that the transition to socialism could be ascertained scientifically as inevitable, independently of what the labourer seeking emancipation, happens to think. Habermas thinks that this conception of history is wrong - justification from history is to be sought from the "structures of linguistically produced intersubjectivity" (Sensat, 1979:161). Marx accurately predicted that the state would tamper with economics, but his conception of history could not foresee that such tampering could not be justified with reference to market faimess. State intervention was, in fact, the signal for the economic door to be opened and for organized labour to demand that the state satisfy their legitimate needs - a function which was standardly left to the market.

Habermas may be wrong because the racist ideology against which Black Consciousness struggled in effect obliterated the distinction between production and socialization. Though Marx equated historical progress with development of the forces of production, his concept of the labouring process is pivotal, and in South Africa served as the springboard of emancipation. In South Africa the economic door was opened to political decision-making, not by virtue of the failure of the ideology of fair market exchange, but rather the failure of a racist ideology. The fact that this increased state power meant that capitalist society in South Africa was forced into a crisis of legitimation pertaining primarily to the validation of norms of political participation for black people.

\section{References}

BELL, D 1995 Communitarianism and its critics. Oxford Clarendon Press

BUCHANAN, A.E. 1982 Marx and justice: the radical critique of liberalism London Methuen.

FALTON, R. 1986. Black consciousness in South Africa Albany : State University of New York Press

HOUNTONDII, P 1983. African philosophy: myth and reality. London : Hutchinson University Library for Africa 
KESSLER, C.S. 1987. Marx as cultural theorist: the prehistory of modern anthropology. (In Austin-Broos, D J. Creating culture. London: Allen and Unwin p. 35-49.)

KYMLICKA, W. 1989. Liberalism, community, and culture Oxford : Clarendon Press

McLAREN, P 1994. White terror and oppositional agency: towards a critical multiculturalism. (In Goldberg, D.T. Multiculturalism Oxford : Blackwell. p. 45-74.)

McLELLAN, D. 1986. Ideology. Milton Keynes : Open University Press

MILIBAND, R. 1990. Marxism and politics. Oxford : Oxford University Press

SENSAT, J Jnr 1979. Habermas and Marxism: an appraisal. London : Sage Publications

THOMPSON, J B. 1990. Ideology and modern culture. Cambridge : Blackwell

THORNTON, R 1988. Culture: a contemporary definition. (In Boonzaier, E. \& Sharp, J South African keywords: the uses and abuses of political concepts. Cape Town : David Phillip. p. 17-28.)

WIREDU, K. 1992. The moral foundations of African culture. (In Flack, H E \& Pellegrino, E D. African-American perspectives on biomedical ethics. Washington DC : Georgetown University Press. p. 80-93.) 